\title{
Defenses of Caribbean sponges against invertebrate predators. I. Assays with hermit crabs
}

\author{
Brett Waddell, Joseph R. Pawlik* \\ Biological Sciences and Center for Marine Science Research, University of North Carolina at Wilmington, Wilmington, \\ North Carolina 28403-3297, USA
}

\begin{abstract}
Hermit crabs (Decapoda: Anomura) are typically omnivorous and are common on Caribbean coral reefs. Sponges are sessile, fleshy, and high in protein and energy content, yet hermit crabs do not appear to prey on them. Assays were performed with the Caribbean reef hermit crab Paguristes punticeps to determine whether secondary metabolites or skeletal elements of Caribbean sponges that were incorporated into artificial foods affected feeding. Of 30 sponge species assayed, 26 $(87 \%)$ yielded organic extracts that deterred feeding by $P$. punticeps. There was substantial interspecific and intraspecific variability in patterns of chemical deterrence. Sponges of the families Axinellidae, Agelasidae, Aplysinidae, Aplysinellidae, and Thorectidae typically yielded deterrent extracts. Three common sponge species, Mycale laevis, Callyspongia vaginalis, and Niphates erecta, were consistently non-deterrent, while other species, including Spheciospongia othella, Chondrilla nucula, Callyspongia plicifera, Niphates digitalis, and Xestospongia muta, were variably deterrent. These results are in general agreement with those of a previous survey of Caribbean sponge chemical defenses using the common reef fish Thalassoma bifasciatum. However, some results differed: Geodia neptuni and lotrochota birotulata were consistently palatable to $T$. bifasciatum, but were deterrent to $P$. punticeps. Several species that were consistently deterrent to $T$ bifasciatum were variably deterrent to P. punticeps, including Aplysina cauliformis, Aplysina fulva, Ircinia strobilina, Amphimedon compressa, and Mycale laxissima. Neither spicules (from Agelas clathrodes, Ectyoplasia ferox, and Xestospongia muta) nor spiculated spongin skeleton (from $A$. clathrodes and $X$. muta) deterred feeding by $P$. punticeps. Spicules and spiculated spongin were similarly non-deterrent to the fish $T$ bifasciatum in a previous survey. The results of this study further suggest that chemical defenses are important in the ecology of Caribbean sponges, while skeletal components do not serve an antipredatory function.
\end{abstract}

KEY WORDS: Sponge Predation $\cdot$ Crab $\cdot$ Chemical defense $\cdot$ Caribbean $\cdot$ Chemical ecology

\section{INTRODUCTION}

Sponges are conspicuous members of tropical benthic communities (Reiswig 1973, Rutzler 1978, Suchanek et al. 1983, Wenner et al. 1983), particularly on coral reefs, where they can rival hard corals in both diversity and abundance (Suchanek et al. 1983, Targett \& Schmahl 1984, Van Soest 1994). Despite being sessile, fleshy, and ostensibly lacking physical protection from predation, sponges thrive in an ecosystem

•Corresponding author.E-mail: pawlikj@uncwil.edu characterized by intense predation pressures (Huston 1985, Jones et al. 1991). Past investigations into sponge antipredatory defenses have focused primarily on 2 attributes of sponges: secondary metabolites that might provide chemical defenses against predation and skeletal constituents, namely siliceous spicules and spongin, that might provide physical defenses (Chanas \& Pawlik 1995, 1996, Pawlik et al. 1995).

The natural products chemistry of tropical marine sponges has been well investigated (Bakus et al. 1986, Scheuer 1990, Faulkner 1998), and many sponge secondary metabolites have been isolated and characterized, including some with potent pharmacological 
activity (Schmitz \& Gopichand 1978, Stonard \& Anderson 1980, Kashman et al. 1989). Only recently have investigators examined the ecological roles of sponge secondary metabolites. Antifouling and UV-protective roles have been suggested for these compounds (Paul 1992, Pawlik 1992, 1993, Henrikson \& Pawlik 1995), although protection from predation is the most commonly proposed function of secondary metabolites. Purified secondary metabolites from sponges have been shown to possess antifeedant properties (Pawlik et al. 1988, Paul 1992, Pawlik 1993, Albrizio et al. 1995). A recent survey using crude extracts from 71 Caribbean sponge species demonstrated antifeedant activity in 44 of the extracts in aquarium assays with the common generalist reef fish Thalassoma bifasciatum (Pawlik et al. 1995).

Physical characteristics of sponges that either increase tissue toughness, decrease digestibility, or both, represent another possible antipredatory defense (Chanas \& Pawlik 1995, 1996). Inorganic siliceous (glass) spicules and organic proteinaceous fibers are the 2 types of skeletal components in demosponges (Bergquist 1978). Spicules are important for support by increasing tissue rigidity in sponge colonies (Bergquist 1978, Koehl 1982), and were hypothesized to provide physical defense by irritating the mouthparts and guts of predators (Randall \& Hartman 1968, Hartman 1981, Wainwright et al. 1982). However, specialist spongivores such as turtles (Meylan 1988), fishes (Randall \& Hartman 1968), and sea urchins (Birenheide et al. 1993) were unaffected by spicules, and laboratory assays with generalist predatory reef fishes have found spicules to be nondeterrent (Chanas \& Pawlik 1995, 1996). Most demosponges also have an internal matrix of proteinaceous fibers called spongin for support (Bergquist 1978). Spongin often constitutes a considerable portion of total colony biomass (Chanas \& Pawlik 1996), and not only does it contribute to the rigidity and toughness of sponge tissue (Storr 1964), but spongin is also hard to digest, thereby potentially reducing the nutritional quality of the sponge (Bjorndal 1990, Meylan 1990). However, the whole sponge skeleton (spongin + spicules) embedded in an artificial food matrix did not deter feeding by generalist predatory fish (Chanas \& Pawlik 1996).

Most studies of sponge antipredatory defenses to date have concentrated on spongivory by reef fishes because predation by fishes is generally believed to have the largest biotic influence on the populations of coral reef benthic invertebrates (Bakus 1964, Hixon 1983). Sponges often harbor many small invertebrates, some of which eat sponge tissue, but they are unlikely to affect sponge distribution significantly (Pawlik 1983). Although there are larger spongivorous invertebrates (Dayton et al. 1974, Pawlik et al. 1988, Bierenheide et al. 1993, Wulff 1995), they are far less common on Caribbean coral reefs than fish predators. Nonetheless, the characterization of sponge antipredatory defenses is incomplete without considering not only invertebrates on coral reefs known to eat sponges, but also the myriad generalist invertebrates found there

Decapod crustaceans occurring in coral reef ecosystems include crabs, spiny lobsters, shrimps, and hermit crabs. Assemblages of decapods in coral reef communities are often high in both diversity and abundance (Abele 1974, 1979). Decapods employ various feeding patterns, including predation, detritivory, and suspension feeding, although these lifestyles indicate tendencies more than strict specialization. Most species of crabs and lobsters are opportunistic omnivores, and vary in their degree of feeding specialization (Warner 1977). Hermit crabs will eat macroscopic pieces of animal matter when available (Hazlett 1968), and some species of hermit crabs actively hunt live prey (Hazlett 1981). However, spongivory by hermit crabs and other relatively large, foraging decapods has not been documented for tropical reefs. In preliminary laboratory assays, Caribbean hermit crabs of the genus Paguristes would not consume sponge tissue (B.W. pers. obs.). Considering that sponges are sessile, soft-bodied, and high in nutritive value (Chanas \& Pawlik 1995), it is pertinent to investigate the feeding responses of hermit crabs to this potential food resource.

To examine the role that chemical and physical characteristics of Caribbean sponges serve as protection from predation by decapod crustaceans, assays were run with the reef hermit crab Paguristes punticeps, a common species found in south Florida and throughout the Caribbean (Provenzanno 1959). Crude organic extracts from 30 species of Caribbean sponges were assayed to determine whether secondary metabolites deter feeding by hermit crabs. Three species differing in spicule concentration and morphology as well as spongin content were used to test the effect of physical constituents on hermit crab feeding: Agelas clathrodes, Ectyoplasia ferox, and Xestospongia muta. Spicule samples from all three sponge species were assayed. Only $A$. clathrodes and $X$. muta were used for whole skeleton (spiculated spongin) assays because the spongin skeleton of $E$. ferox was too fragile to isolate (see further discussion in Chanas \& Pawlik 1996).

\section{MATERIALS AND METHODS}

Sponge collection. Tissues from colonies of 30 species of Caribbean sponges were collected during 5 research expeditions at the National Undersea Research Program facility in Key Largo, Florida, USA, in May 1996. August 1996, May 1997, August 1997, and De- 
cember 1997, and during 1 expedition to the Bahamas aboard the RV 'Seward Johnson' in June-July 1996. Replicate samples of sponge tissue for each species were collected from distant sites $(>2 \mathrm{~km}$ ) to avoid collecting asexually produced clones and to examine levels of intraspecific variability in chemical defenses. Portions of sponge colonies were collected by cutting the tissue with a sharp knife. Sponges were identified based on spicule and tissue preparations (Zea 1987. R. W. M. Van Soest unpubl.). Samples were stored at $-20^{\circ} \mathrm{C}$ until they could be used for extractions or isolation of physical constituents (i.e. spicules or spongin skeleton).

Assays of crude extracts. Frozen sponge tissue was cut into approximately $1 \mathrm{~cm}^{3}$ pieces and added to $80 \mathrm{ml}$ of methanol in a graduated cylinder to a final volume

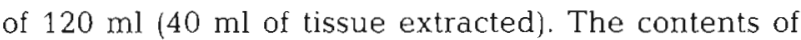
the graduated cylinder were emptied into a $125 \mathrm{ml}$ Nalgene bottle and allowed to extract for $24 \mathrm{~h}$ at $4^{\circ} \mathrm{C}$. The resulting methanol:seawater extract was filtered through Celite 545 diatomaceous earth by vacuum filtration, and the methanol was evaporated on a rotary evaporator at low heat $\left(<50^{\circ} \mathrm{C}\right)$. The remaining water was placed in a $20 \mathrm{ml}$ scintillation vial and evaporated on a vacuum concentrator at low heat $\left(<40^{\circ} \mathrm{C}\right)$. After the methanol extraction was repeated, the remaining tissue was extracted in a 1:1 mixture of dichloromethane and methanol as above. The dichloromethane: methanol mixture was filtered and evaporated to dryness, and the extract was recovered into the scintillation vial. The dichloromethane:methanol extraction was repeated, and the crude extract was stored under nitrogen at $-20^{\circ} \mathrm{C}$ until used in aquarium assays.

Assays were based on the screen gel assay described in Hay et al. (1994). This method involves forming artificial food onto fiberglass window screening material, which supports the gel and provides an internal grid so that the amount of artificial food eaten can be quantified by counting the number of squares cleared of the gel. The artificial food consisted of $2.0 \mathrm{~g}$ of lyophilized, powdered squid mantle and $0.4 \mathrm{~g}$ of carrageenan per $40 \mathrm{ml}$ of gel, a mixture which approximates the mean protein content of Caribbean sponges (Chanas \& Pawlik 1996). The squid and carrageenan were added to $38 \mathrm{ml}$ of distilled water and heated in a microwave oven for $50 \mathrm{~s}$. Immediately upon removing the hot gel from the microwave oven, the crude sponge extract resuspended in $7 \mathrm{ml}$ of methanol was poured into the gel and stirred vigorously to assure uniform mixing. This treatment gel was then poured into one channel of a Formica mold, under which the window screening was held (see Hay et al. 1994 for details). Control gels were made using $7 \mathrm{ml}$ of methanol without any extract to control for solvent effects and were poured into the channel adjacent to the treatment gel. Commercial food coloring was added to both gels prior to heating to avoid feeding differences due to color. Enough methanol and water evaporated due to heating to give the gels a final volume of $40 \mathrm{ml}$. Once the gels had cooled, the screens were cut perpendicular to the gels so that each screen had both treatment and control gels on it, each measuring $8 \times 13$ squares.

Assays were performed at the wet laboratory of the University of North Carolina at Wilmington at Wrightsville Beach, NC (USA). Paguristes punticeps were collected at Sweetings Cay, Grand Bahama Island, Bahamas, in July 1996. Crabs were maintained in $160 \mathrm{l}$ aquaria, each divided into 5 cells with 1 hermit crab in each cell, with a constant flow of sand-filtered seawater provided to each aquaria. Crabs were fed every day on a mixed diet of fish or squid pieces or commercial fish food, but were not fed on days when they were used for assay experiments. Each crab was assayed only once for each comparison. For each assay, a hermit crab was offered a screen and was allowed to feed for $1 \mathrm{~h}$, after which time the screen was recovered, and the number of squares eaten of both control and treatment gels was recorded. The Wilcoxon pairedsample test (1-tailed) was used to determine whether feeding on treatment gels was significantly reduced relative to feeding on control gels (Zar 1984). Crabs that did not feed on either gel were not used in statistical analyses. Most non-feeding events $(\sim 90 \%)$ occurred within $3 \mathrm{~d}$ prior to or $3 \mathrm{~d}$ after molting by the hermit crabs.

The fully replicated assay was completed at least 3 times with tissue from geographically distant collections of the same sponge species (replicate tissue samples) for each species except Exylus formosus in order to examine the degree of intraspecific variability in chemical defenses of these sponges. Data from these experiments are reported separately (rather than combined, with only means reported) to demonstrate the degree of intraspecific variation.

Assays of spicules. Spicules were obtained by completely oxidizing $40 \mathrm{~cm}^{3}$ of sponge tissue in 2 to 6 changes of household bleach $15 \%$ sodium hypochlorite). Spicules were then rinsed twice with $0.1 \mathrm{M}$ sodium thiosulfate to neutralize residual sodium hypochlorite, and rinsed thoroughly with distilled water. Screen gels for aquarium assays were made as above, except that the volume of distilled water was increased to $43 \mathrm{ml}$, and methanol was omitted. After heating, the final gel volume was still $40 \mathrm{ml}$. Screens with treatment gels (squid/carrageenan food + spicules) and control gels (squid/carrageenan food only) were assayed on Paguristes punticeps, and the data were analyzed as above

Assays of whole sponge skeleton. Whole sponge skeleton (spiculated spongin) was obtained as in Chanas 
\& Pawlik (1996) by lyophilizing $40 \mathrm{~cm}^{3}$ of sponge tissue and then extracting the tissue sequentially in methanol and 1:1 dichloromethane:methanol, each for $24 \mathrm{~h}$, to remove the cellular material. The skeleton was dried, submerged in $0.5 \%$ sodium hypochlorite to remove any remaining cellular material, rinsed with $0.1 \mathrm{M}$ sodium thiosulfate, and thoroughly rinsed with distilled water. The skeleton was thinly sliced $(\sim 1$ to $2 \mathrm{~mm}$ ) and incorporated into screen gels by arranging the skeleton in the treatment channel of the mold and pouring the squid/carrageenan food over it. Screens with both treatment and control gels were assayed on Paguristes punticeps, and the data were analyzed as above.

\section{RESULTS}

The ability of sponge organic extracts to deter feeding by Paguristes punticeps varied considerably among species (Fig. 1). At least 1 replicate tissue sample from 26 of the 30 species assayed $(87 \%)$ yielded a deterrent extract. Using the taxonomic designations of Pawlik et al. (1995), a majority of replicate samples yielded deterrent extracts from all species from the families Aplysinidae (Aplysina cauliformis, A. fistularis, and Verongula gigantea), Thorectidae (Ircinia felix and I. strobilina) and Agelasidae (Agelas clathrodes, A. conifera, and $A$. wiedenmayeri). Two of 3 species in the Axinellidae (Ptilocaulis spiculifera, Ulosa ruetzleri)
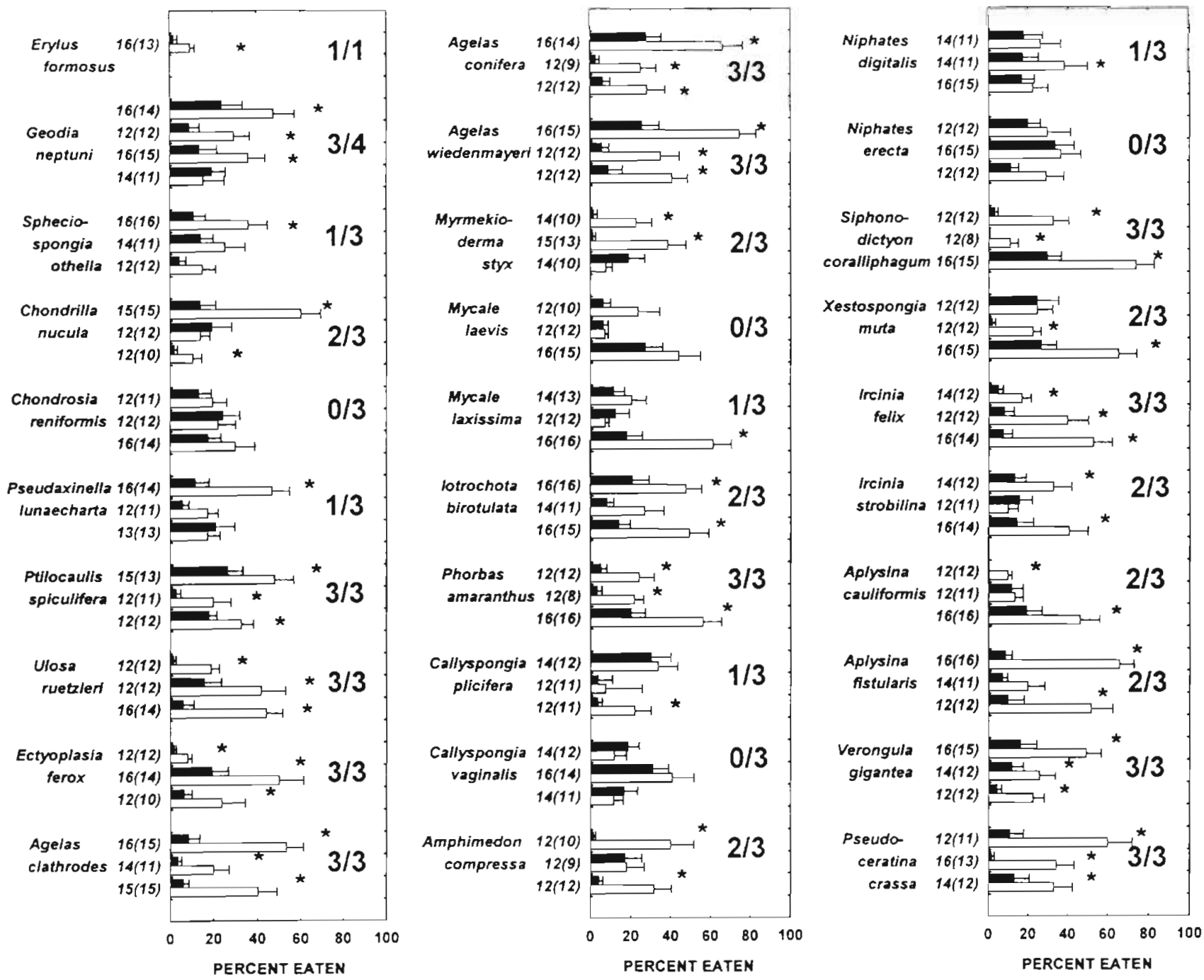

CONTROL

TREATMENT

Fig. 1. Aquarium feeding assays of crude organic extracts of sponges in foods offered to Paguristes punticeps. Values expressed as mean percentage of squares eaten $+1 \mathrm{SE}$. (*) Significant difference in feeding between control and treatment gels as computed by Wilcoxon paired-samples test $(\mathrm{p}<0.05)$. Numbers to left of pairs of bars = number of hermit crabs offered a screen (number of hermit crabs used in statistical analysis). Numbers to right of sets of bars for each sponge species = proportion of repeated experiments using extracts from different sponge samples of the same species that were significantly deterrent 


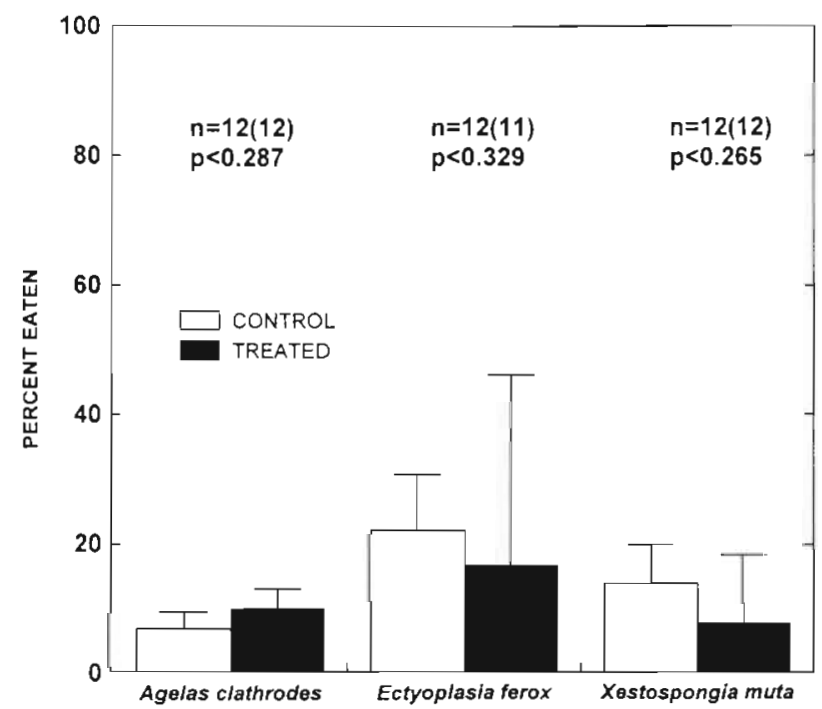

Fig. 2. Aquarium feeding assays of sponge spicules incorporated into foods offered to Paguristes punticeps. Values expressed as mean number of squares eaten +1 SE. p-values computed by Wilcoxon paired-samples test. $\mathrm{n}=$ number of hermit crabs used in assay (number of hermit crabs used in statistical analysis)

yielded extracts that were consistently deterrent, while Pseudaxinella lunaecharta was deterrent in 1 of 3 replicate assays. Four species yielded consistently non-deterrent extracts: Callyspongia vaginalis, Mycale laevis, Niphates erecta, and Chondrosia reniformis.

The deterrency of extracts from distantly collected individuals varied for many species, in particular Callyspongia plicifera, Chondrilla nucula, Geodia nep-

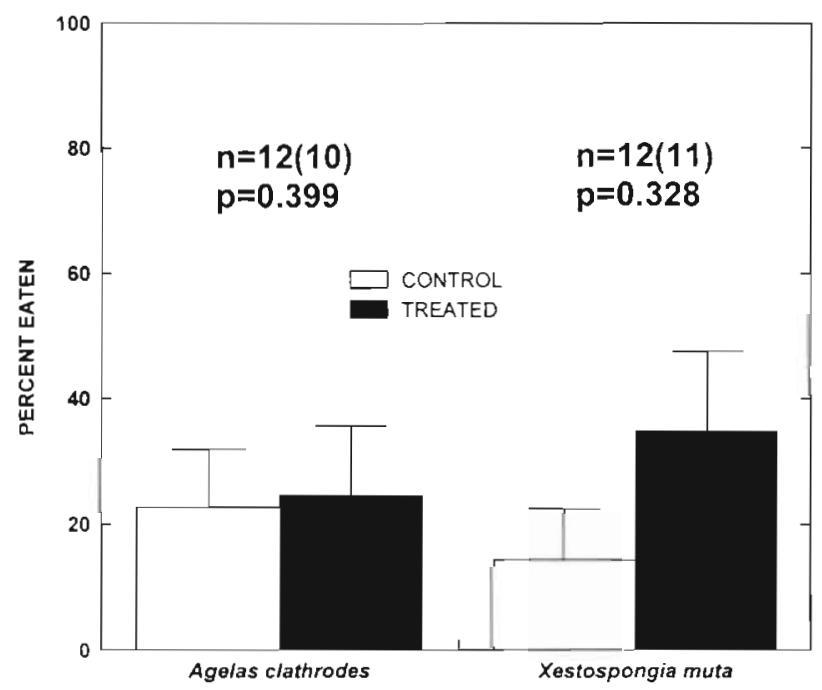

Fig. 3. Aquarium feeding assays of sponge spiculated skeleton incorporated into foods offered to Paguristes punticeps. Values expressed as mean number of squares eaten $+1 \mathrm{SE}$. p-values computed by Wilcoxon paired-samples test. $n=$ number of hermit crabs used in assay (number of hermit crabs used in statistical analysis) tuni, Iotrochota birotulata, Niphates digitalis, Spheciospongia othella, and Xestospongia muta.

Spicules did not deter feeding by Paguristes punticeps for any of the 3 species tested (Fig. 2). Likewise, spiculated spongin from Agelas clathrodes and Xestospongia muta did not deter feeding by $P$. punticeps (Fig. 3), although the hermit crabs did not actually consume the spongin skeleton, but picked the squid/ carrageenan food from the surface. Due to the microscopic scale at which these hermit crabs consume food, squares with spongin cleared of squid/carrageenan food were considered eaten (see 'Discussion').

\section{DISCUSSION}

Previous studies have concentrated on antipredatory defenses of Caribbean demosponges against fishes because fishes are the dominant grazers and predators in tropical reef ecosystems (Huston 1985). Even among fishes, however, only a few species of spongivores exist (Randall \& Hartman 1968, Dunlap \& Pawlik 1996. 1998). Several hypotheses have been proposed in the past to explain this paucity of sponge-eating predators. Sponges have long been known to produce toxic compounds, and, until recently, biologists and natural products chemists inferred chemical defense from toxicity data (Green 1977, 1991, Bakus \& Thun 1979). However, more recent ecologically relevant studies have found little or no correlation between the toxicity of sponge metabolites and their capacity to deter predation (Schulte \& Bakus 1992, Pawlik et al. 1995). Spicules were also hypothesized to serve an antipredatory function, presumably by irritating the mouthparts and guts of predators (Randall \& Hartman 1968, Hartman 1981, Wainwright et al. 1982). However, many spongivores ingest spicules without apparent ill effects (fishes: Randall \& Hartman 1968, Wulff 1994; turtles: Meylan 1988; urchins: Birenheide et al. 1993). In aquarium and field assays with generalist reef fishes, sponge spicules did not deter feeding unless the nutritional quality of the artificial food was at least 10 times lower than that of typical sponge tissue (Chanas \& Pawlik 1995, 1996). Another hypothesis suggested that refractory spongin and indigestible siliceous spicules resulted in tissue of sufficiently low nutritional quality to deter predators. However, spiculated spongin did not deter feeding by generalist reef fishes in either aquarium or field assays (Chanas \& Pawlik 1996), and sponges are often high in both protein and energy content (Pawlik et al. 1995). Recent studies suggest that for many sponges, secondary metabolites are the principal form of antipredatory defense, while spicules and spongin appear to serve a primarily structural role (Chanas \& Pawlik 1995, 1996, Pawlik et al. 1995). 
The results of this study are in agreement with the conclusions of previous recent investigations into sponge defenses against fish predators. The patterns of chemical deterrency against hermit crabs (Fig. 1) agree well with those performed using the generalist reef fish Thalassoma bifasciatum reported by Pawlik et al. (1995) (Table 1). In particular, sponges of the families Axinellidae, Agelasidae, Thorectidae and Aplysinidae were largely deterrent in both studies. Four species, Callyspongia vaginalis, Mycale laevis, Niphates erecta, and Chondrosia reniformis, were consistently non-deterrent in both studies. Species that showed intraspecific variability in chemical defenses in both studies include Pseudaxinella lunaecharta, Chondrilla nucula, Spheciospongia othella, Callyspongia plicifera, Niphates digitalis, and Xestospongia muta. A few species that were consistently deterrent against fishes were more variable against hermit crabs: Mycale laxissima, Amphimedon compressa, Ircinia strobilina, and Aplysina spp. Regardless, the overall similarity in the patterns of deterrency against fishes and hermit crab predators is compelling. The most notable differ-

Table 1. Comparison of deterrency of organic extracts of Caribbean sponges to fishes Thalassoma bifasciatum and hermit crabs Paguristes punticeps in aquarium feeding assays. $+=$ consistently non-deterrent $;-=$ consistently deterrent; $\mathrm{V}=$ variably deterrent. Fish data taken from Pawlik et al. (1995)

\begin{tabular}{|lcc|}
\hline Sponge & Fish assay & Crab assay \\
\hline Agelas clathrodes & - & - \\
Agelas conifera & - & - \\
Agelas wiedenmeyeri & - & - \\
Amphimedon compressa & - & $\mathrm{V}$ \\
Aplysina cauliformis & - & $\mathrm{V}$ \\
Aplysina fistularis & - & $\mathrm{V}$ \\
Callyspongia plicifera & $\mathrm{V}$ & $\mathrm{V}$ \\
Callyspongia vaginalis & + & + \\
Chondrilla nucula & $\mathrm{V}$ & $\mathrm{V}$ \\
Chondrosia reniformis & + & + \\
Ectyoplasia ferox & - & - \\
Erylus formosus & - & - \\
Geodia neptuni & + & $\mathrm{V}$ \\
lotrochota birotulata & + & $\mathrm{V}$ \\
Ircinia felix & - & - \\
Ircinia strobilina & - & $\mathrm{V}$ \\
Mycale laevis & + & + \\
Mycale laxissima & - & $\mathrm{V}$ \\
Myrmekioderma styx & - & $\mathrm{V}$ \\
Niphates digitalis & $\mathrm{V}$ & $\mathrm{V}$ \\
Niphates erecta & + & + \\
Phorbas amaranthus & - & - \\
Pseudaxinella lunaecharta & $\mathrm{V}$ & $\mathrm{V}$ \\
Pseudoceratina crassa & - & - \\
Siphonodictyon coralliphagum & - & - \\
Spheciospongia othella & $\mathrm{V}$ & $\mathrm{V}$ \\
Ulosa ruetzleni & - & - \\
Verongula gigantea & - & \\
Xestospongia muta & $\mathrm{V}$ & \\
& & \\
\hline
\end{tabular}

ence involves the species Geodia neptuni and Iotrochota birotulata, which were both highly palatable to $T$. bifasciatum, but were mostly unpalatable to Paguristes punticeps (G. neptuni: 3/4 deterrent; I. birotulata: $2 / 3$ deterrent). These 2 species appear to be good candidates for attempting to isolate taxon-specific antifeedant metabolites

Past studies with Thalassoma bifasciatum have found that neither spicules nor spiculated spongin deter feeding by generalist fishes (Chanas \& Pawlik 1995, 1996). The present study also found spicules (Fig. 2) and spiculated spongin (Fig. 3) to be non-deterrent to feeding by Paguristes punticeps. In assays with spiculated spongin, the crabs did not actually consume the skeleton, but merely picked the squid/carrageenan food from the surface. As in our previous work (Chanas \& Pawlik 1995, 1996), we chose sponge species with a high density of large spicules for our assays; most sponges possess fewer spicules, or none at all, and we considered them less likely to use structural materials as a defensive option (see Chanas \& Pawlik 1995, 1996). P. punticeps is a small hermit crab (carapace length $\leq 20 \mathrm{~mm}$ ) that tears off very small pieces of food. It seems reasonable that, if it found a sponge palatable, a hermit crab could remove small pieces of tissue, even from sponges with hard or dense skeletons, and the skeleton would offer no defense. Larger decapods exist on most coral reefs that should be able to tear even the hardest sponges. Therefore, the skeletal components of Caribbean demosponges do not appear to deter feeding by decapods.

Most recent evidence suggests that chemical defenses from secondary metabolites are the primary antipredatory strategy employed by Caribbean demosponges. However, three of the species that yielded extracts that were consistently non-deterrent against both fish and hermit crabs-Callyspongia vaginalis, Mycale laevis, and Niphates erecta-were among the 10 most common species in a composite abundance ranking of sponges on shallow reefs in four areas of the Caribbean (Pawlik et al. 1995). If structural components do not provide protection from predation, and chemical defenses are not elaborated by these species, then presumably they employ some other strategy to maintain their abundance. Many of the secondary metabolites isolated from sponges have complex carbon chains (e.g. heterocycles) and may be nitrogenand/or halogen-rich (Paul 1992, Faulkner 1998). Because coral reefs are generally nutrient-poor environments (Webb et al. 1975) and halogenating enzymes are rare among animals (Nieldelman \& Geigert 1986), secondary metabolites are presumed to be metabolically expensive for sponges to produce (Paul 1992). Seemingly, sponges that do not elaborate chemical defenses could shunt that metabolic energy into some 
other strategy, such as growth (analogous to grasses among terrestrial plants) or fecundity. Studies are currently underway to determine whether common, chemically undefended sponges employ either of these strategies.

This study represents the first comprehensive attempt to determine whether physical or chemical characteristics of Caribbean sponges provide protection against predation by foraging crustaceans. It confirms the findings of earlier studies concerned with sponge defenses against predatory fishes, namely, that chemical defense is an important strategy for many Caribbean sponges, while skeletal components appear to serve some other function.

Acknowledgements. This research was made possible by funding from National Science Foundation grants OCE9314145 and OCE-9711255 (to J.R.P.); from NOAA/NURP grants UNCW9414, 9523, and 9709 (to J.R.P.); and from UNCW/CMSR Summer Research Fellowships in 1997 and 1998 (to B.W.). A number of people provided invaluable help throughout this project, particularly Greg McFall, Matt Dunlap, Sebastian Engel, Robyn Palmer, Monica Puyana, Joe Stack, Mariah Humphrey, Andy Rhyne, and Mike Baker. Dr Mark Hay of the University of North Carolina at Chapel Hill gave valuable advice about performing the screen gel assays. We thank the captain and crew of the RV 'Seward Johnson' and the staff at the National Oceanic and Atmospheric Administration (NOAA)/National Undersea Research Center at Key Largo, Florida. Thanks are due to the government of the Bahamas for permission to perform research in their territorial waters. This is contribution 241 from UNCW's Center for Marine Science Research.

\section{LITERATURE CITED}

Abele LG (1974) Species diversity of decapod crustaceans in marine habitats. Ecology 55:156-161

Abele LG (1979) The community structure of coral-associated decapod crustaceans in variable environments. In: Livingston RJ (ed) Ecological processes in coastal and marine systems. Plenum Press, New York, p 265-286

Albrizio S, Ciminiello P, Fattorusso E, Magno S, Pawlik JR (1995) Amphitoxin: a new high molecular weight antifeedant pyridinium salt from the Caribbean sponge Amphimedon compressa. J Nat Prod (Lloydia) 58:647-652

Bakus GJ (1964) The effects of fish-grazing on invertebrate evolution in shallow tropical water. Allan Hancock Foundation Occas Pap 27:1-29

Bakus GJ, Thun M (1979) Bioassays on the toxicity of Caribbean sponges. Colloq Int Cent Natl Rech Sci 291:471-422

Bakus GJ, Targett NM, Schulte B (1986) Chemical ecology of marine organisms: an overview. J Chem Ecol 12:951-987

Bergquist PR (1978) Sponges. University of California Press, Berkeley

Birenheide R, Amemiya S, Motokawa T (1993) Penetration and storage of sponge spicules in tissues and coelom of spongivorous echinoids. Mar Biol 115:677-683

Bjorndal KA (1990) Digestibility of the sponge Chondrilla nucula in the green turtle, Chelonia mydas. Bull Mar Sci 47:567-570

Chanas B, Pawlik JR (1995) Defenses of Caribbean sponges against predatory reef fish. II. Spicules, tissue toughness, and nutritional quality. Mar Ecol Prog Ser 127:195-211

Chanas B, Pawlik JR (1996) Does the skeleton of a sponge provide a defense against predatory reef fish? Oecologia 107:225-231

Dayton PK, Robilliard GA, Paine RT, Dayton LB (1974) Biological accomodation in the benthic community at MCMurdo Sound, Antarctica. Ecol Monogr 44:105-128

Dunlap M. Pawlik JR (1996) Video-monitored predation by caribbean reef fishes on an array of mangrove and reef sponges. Mar Biol 126:117-123

Dunlap M, Pawlik JR (1998) Spongivory by parrotfish in Florida mangrove and reef habitats. PSZN I: Mar Ecol 19: $325-337$

Faulkner DJ (1998) Marine natural products. Nat Prod Rep (Lloydia) 15:113-158

Green $G$ (1977) Ecology of toxicity in marine sponges. Mar Biol 40:207-215

Green G, Gomez P, Bakus GJ (1991) Antimicrobial and ichthyotoxic properties of marine sponges from Mexican waters. In: Rutzler $\mathrm{K}$ (ed) New perspectives in sponge biology. Smithsonian Institution Press, Washington, DC, p 109-114

Hartman WD (1981) Form and distribution of silica in sponges. In: Simpson TL, Volcani BE (eds) Silicon and siliceous structures in biological systems. Springer, New York, p 454-493

Hay ME, Kappel QE, Fenical W (1994) Synergisms in plant defenses against herbivores: interactions of chemistry, calcification, and plant quality. Ecology 75:1714-1726

Hazlett BA (1968) Stimuli involved in the feeding behavior of the hermit crab Clibanarius vittatus (Decapoda, Paguridea). Crustaceana 15:305-311

Hazlett BA (1981) The behavioral ecology of hermit crabs. Annu Rev Ecol Syst 12:1-22

Henrikson AA, Pawlik JR (1995) A new antifouling assay method: results from field experiments using extracts of four marine organisms. J Exp Mar Biol Ecol 194:157-165

Hixon MA (1983) Fish grazing and community structure of coral reefs and algae: a synthesis of recent studies. In: Reaka ML (ed) The ecology of deep and shallow coral reefs (Symposia series for Undersea Research). NOAA/ NURP, Washington, DC, p 79-87

Huston MA (1985) Patterns of species diversity on coral reefs. Annu Rev Ecol Syst 16:149-177

Jones GP, Ferrell DJ, Sale PF (1991) Fish predation and its impact on the invertebrates of coral reefs and adjacent sediments. In: Sale PF (ed) The ecology of fishes on coral reefs. Academic Press, New York, p 156-179

Kashman Y, Hirsh S, McConnell OJ, Ohtani I, Kusumi T, Kakisawa $H$ (1989) Ptilomycalin A: a novel polycyclic guanidine alkaloid of marine origin. J Am Chem Soc 111. 8925-8926

Koehl MAR (1982) Mechanical design of spicule-reinforced connective tissue: stiffness. J Exp Biol 98:239-267

Meylan A (1988) Spongivory in hawksbill turtles: a diet of glass. Science 239:393-395

Meylan A (1990) Nutritional characteristics of sponges in the diet of the hawksbill turtle, Eretmochelys imbricata. In: Rutzler K (ed) New perspectives in sponge biology. Smithsonian Institution Press, Washington, DC, p 472-477

Neidelman SL, Geigert J (eds) (1986) Biohalogenation: principles, basic roles, and applications. Halsted Press, New York

Paul VJ (1992) Chemical defenses of benthic marine invertebrates. In: Paul V (ed) Ecological roles of marine natural products. Comstock Publishing, Ithaca, NY, p 164-188

Pawlik JR (1983) A sponge-eating worm from Bermuda: Bran- 
chiosyllis oculata (Polychaeta, Syllidae). PSZN I: Mar Ecol $4: 65-79$

Pawlik JR (1992) Chemical ecology of the settlement of benthic marine invertebrates. Ocenogr Mar Biol Annu Rev 30 $273-335$

Pawlik JR (1993) Marine invertebrate chemical defenses. Chem Rev 93:1911-1922

Pawlik JR, Kernan MR, Molinski TF, Harper MK, Faulkner DJ (1988) Defensive chemicals of the Spanish dancer nudibranch Hexabranchus sanguineus and its egg ribbons: macrolides derived from a sponge diet. J Exp Mar Biol Ecol 1 19:99-108

Pawlik JR, Chanas B, Toonen RJ, Fenical W (1995) Defenses of Caribbean sponges against predatory reef fish. I. Chemical deterrency. Mar Ecol Prog Ser 127:183-194

Provenzanno AJ Jr (1959) The shallow water hermit crabs of Florida. Bull Mar Sci Gulf Caribb 9:349-420

Randall JE, Hartman WE (1968) Sponge feeding fishes of the West Indies. Mar Biol 1:216-225

Reiswig HM (1973) Population dynamics of three Jamaican Demospongiae. Bull Mar Sci 23:191-226

Rutzler K (1978) Sponges in coral reefs. In: Stoddart DR, Johannes RE (eds) Coral reefs: research methods. Monographs on oceanographic methodology, no 5. UNESCO, Paris, p 299-314

Scheuer PJ (1990) Some marine ecological phenomena: chemical basis and biochemical potential. Science 248 : $173-177$

Schmitz FJ, Gopichand RJ (1978) A novel dibromoacetylene acid from the marine sponge Xestospongia muta. Tetrahedron Lett 1978:3637-3640

Schulte BA, Bakus GJ (1992) Predation deterrence in marine sponges: laboratory versus field studies. Bull Mar Sci 50: $205-211$

Stonard RJ, Andersen RJ (1980) Celenamides A and B, linear peptide alkaloids from the sponge Cliona celata. J Org Chem 45:3687-3691

Storr JF (1964) Ecology of the Gulf of Mexico commercial

Editorial responsibility: Otto Kinne (Editor),

Oldendorf/Luhe, Germany sponges and its relation to the fishery (Special scientific report-Fisheries 466) US Fish and Wildlife Service, Washington, DC, p 1-73

Suchanek TH, Carpenter RC, Witman JD, Harvell CD (1983) Sponges as important space competitors in deep Caribbean coral communities. In: Reaka M.L (ed) The ecology of deep and shallow coral reefs (Symposia series for Undersea Research 1). National (iceanic and Atmospheric Administration, Washington, DC , p 55-60

Targett NM, Schmahl GP (1984) Chemical ecology and distribution of sponges in the Salt River Canyon, St. Croix, U.S.V.I. NOAA Tech Mem OAR NURP-1, Rockville, MD

Van Soest RWM (1994) Demosponge distribution patterns. In: Van Soest RWM, Van Kempen TMG, Braekman JC (eds) Sponges in time and space. Balkema, Rotterdam, p $213-223$

Wainwright SA, Biggs WD, Currey JD, Gosline JM (1982) Mechanical design in organisms. Princeton University Press, Princeton

Warner GF (1977) The biology of crabs. Van Nostrand Reinhold, New York

Webb KL, DePaul WD, Wiebe W, Sottile W, Johannes RE (1975) Enewetak (Eniwetok) Atoll: aspects of the nitrogen cycle on a coral reef. Limnol Oceanogr 20:198-210

Wenner EL, Knott DM, VanDolah RF, Burrell VG (1983) Inver tebrate communities associated with hard bottom habitats in the South Atlantic Bight. Estuar Coast Shelf Sci 17: $143-150$

Wulff JL (1994) Sponge feeding by Caribbean angelfishes, trunkfishes, and filefishes. In: VanSoest RWM, VanKempen TMG, Braekman JC (eds) Sponges in time and space. Balkema, Rotterdam, p 265-27 1

Wulff JL (1995) Sponge-feeding by the Caribbean starfish Oreaster reticulatus. Mar Biol 123:313-325

Zar JH (1984) Biostatistical analysis, 2nd edn. Prentice-Hall, Englewood Cliffs

Zea S (1987) Esponjas del Caribe Colmbiano. Editorial Catalogo Cientifico, Santa Marta

Submitted: May 14, 1999; Accepted: October 13, 1999

Proofs received from author(s): March 8, 2000 